\title{
ポーラスマグネシウムの発泡特性および気孔性状に 及ぼすプリカーサ加熱条件の影響
}

\author{
小橋 眞 $*$. 前原 一仁 **. 金武 直幸 $*$
}

Journal of Japan Institute of Light Metals, Vol. 59, No. 5 (2009), pp. 261-264

\author{
Effect of thermal condition on blowing behavior \\ and pore morphology of porous magnesium
}

\begin{abstract}
Makoto KOBASHI*, Kazuhito MAEHARA** and Naoyuki KANETAKE*
Porous magnesium was fabricated from a precursor made of AZ91 magnesium machined chips. The effect of thermal conditions (heating rate, heating temperature and cooling rate) of the precursor on foaming behavior and pore morphology was investigated. The precursor started to expand at around the solidus temperature of AZ91 magnesium alloy, and accelerated its expansion rate after the temperature exceeded the liquids line. The maximum expansion was sustained only for a few seconds, and the specimen shrunk rapidly by heating the specimen continuously. The degree of maximum expansion became higher and the pore size became smaller by increasing the heating rate from $1 \mathrm{~K} / \mathrm{s}$ to $3 \mathrm{~K} / \mathrm{s}$. The porosity of porous magnesium increased by increasing the processing temperature up to $660^{\circ} \mathrm{C}$, whereas the pore size became larger and inhomogeneous. The cooling rate also turned out to be an important factor to maintain high porosity. With the low cooling rate, pores tended to collapse and porosity became lower during the cooling period.
\end{abstract}

(Received December 17, 2008 Accepted January 22, 2009)

Keywords: porous magnesium, foaming behavior, precursor method, magnesium chip

\section{1. 緒言}

材料内部に多量の気孔を含有するポーラス金属は, 弾性率 が気孔率に応じて可変であり，断熱性が高い，衝撃吸収性能 が高い, 表面積が大きい, 流体透過性・フィル夕性能を有す る, 吸音特性が高いなど緻密材料には見られない様々なユ ニークな特徵を示す ${ }^{1) ~ 3) 。 そ の た め, ~ ク ラ ッ シ ュ エ レ メ ン ト, ~}$ 生体硬組織代替材料, フィル夕, 断熱材, 触媒担持体, 気化 器など多様な分野への適用が検討されている4)。特に, 超軽 量（気孔率 70\%のポーラスアルミニウムの比重が約 0.8） と いう特徵から，アルミニウムやマグネシウムなどの軽金属材 料のポーラス化に関する研究が盛んである。しかしながら, ポーラスアルミニウムの研究例と比較して, ポーラスマグネ シウムに関する研究報告は少ないのが現状である。この理由 の一つとして，ポーラス金属の代表的な製造方法であるプリ カーサ法5) 7) は，金属粉末を原料とすることが多いため，マ グネシウムへの適用が困難なプロセスであることが挙げられ る。筆者らは，ポーラス金属の前駆体であるプリカーサを金 属粉末からではなく, 切削チップを原料として $\mathrm{TiH}_{2}$ 粉末と ともに圧縮衫じり加工を施して製造する方法を開発した ${ }^{8), 99}$ 。 この方法により, 気孔率が $70 \%$ を越えるポーラスマグネシウ ムを, 安全に製造可能であることを報告した10)。ただし，プ リカーサの発泡特性（膨張および収縮の量および速度）や ポーラスマグネシウムの気孔性状（気孔率, 気孔の大きさ,
形状，分布など）の制御については重要な課題として残され ていた。一般に，プリカーサ法によるポーラス金属製造では， プリカーサの加熱および柃却条件は発泡特性や気孔性状に影

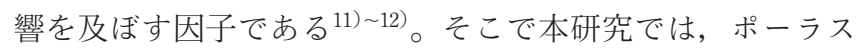
マグネシウム製造時の昇温速度, 加熱温度と冷却条件の影響 について検討したので，その結果を記す。

\section{2. 実験方法}

本研究ではプリカーサの原料として, Fig. 1 に示す AZ91

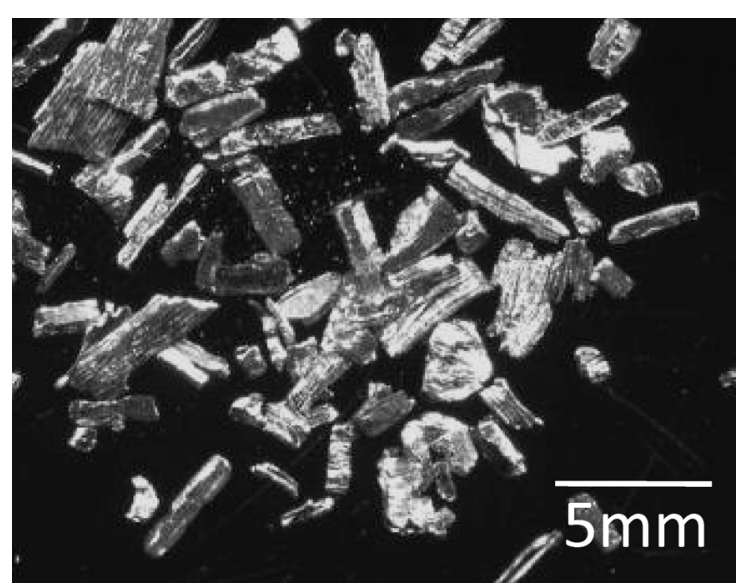

Fig. 1 Photograph of AZ91 magnesium machined chips.

\footnotetext{
*名古屋大学（广 464-8603 愛知県名古屋市千種区不老町 1)。Nagoya University (1 Furo-cho, Chikusa-ku, Nagoya-shi, Aichi 464-8603). E-mail: kobashi@numse.nagoya-u.ac.jp

**名古屋大学大学院生（名古屋市）〔現在：(烌豊田自動織機〕 Graduate Student, Nagoya University (Nagoya-shi, Aichi)〔Present: Toyota Industries Corporation].
} 


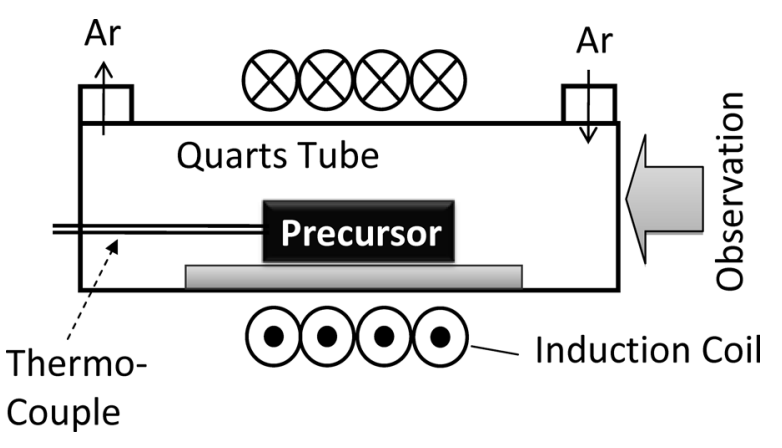

Fig. 2 Schematic illustration of experimental apparatus.

マグネシゥム合金切削チップを用いた。この AZ91 合金切削 チップをアセトンで 20 分間超音波洗浄した後, $\mathrm{TiH}_{2}$ 粉末 （粒径： $45 \mu \mathrm{m}$ ）を $1.0 \mathrm{mass} \%$ 添加し，乳鉢で 20 分間混合し た。切削チップと $\mathrm{TiH}_{2}$ の混合物を圧粉压力 $400 \mathrm{MPa}$ で冷間 予備圧粉し, 圧縮ねじり加工装置のコンテナ（内径 $\phi 40 \mathrm{~mm}$ ) に入れ, 加工圧力 $100 \mathrm{MPa}$, 加工温度 $400^{\circ} \mathrm{C}$, 回転回数 30 回, 回転速度 $5 \mathrm{rpm}$ で圧縮ねじり加工を行った。この圧縮ね じり加工ビレットを押出温度 $400^{\circ} \mathrm{C}$, 押出比 16 (断面形状 $10 \mathrm{~mm} \times 8 \mathrm{~mm}$ ）で押出加工を施した後に切断し， $8 \times 10 \times$ $20 \mathrm{~mm}$ のプリカーサを作製した。プリカーサには，ドリルを 用い穴を開け，そこへ熱電対を挿入して，発泡過程のプリ カーサ温度を直接測定できるようにした。

プリカーサの加熱には Fig. 2 に示す高周波誘導加熱装置を 用い, アルゴンガス雾囲気中で試料を作製した。昇温速度の 影響調査に関する実験では， $400 \sim 600^{\circ} \mathrm{C}$ の間の平均昇温速度 が $1 \mathrm{~K} / \mathrm{s}, 2 \mathrm{~K} / \mathrm{s}, 3 \mathrm{~K} / \mathrm{s}$ となるように加熱装置の出力を变えてプ リカーサの発泡特性を調査した。プリカーサの発泡特性は, Fig. 2 に示すように試料側面からビデオカメラで撮影し，そ の映像を画像解析装置を用い, 次式（1）で定義される相対 投影面積を用いて評価した ${ }^{13)}$ 。

$$
A_{r}=A_{t} / A_{\text {ini }}
$$

ここで, $A_{r}$ : 相対投影面積, $A_{t}$ : 加熱中の試料投影面積, $A_{i m i}:$ 加熱前のプリカーサ投影面積である。

気孔率および気孔サイズの評価は，プリカーサの投影面積 が最大となるまで加熱した後, He ガスにより急速冷却した試 料を用いて行った。それぞれの実験で得られた発泡試料につ いて，アルキメデス法により密度を測定し，気孔率を算出し た。試料断面の画像解析により気孔の数および気孔径（面積 相当円直径) を求めた。なお, 解像度の制約により, 面積相 当円直径が $0.2 \mathrm{~mm}$ 未満の気孔については解析から除外した。

\section{3. 結果}

\section{1 AZ91 合金プリカーサの発泡特性の観察}

Fig. 3 に加熱中の AZ91 合金プリカーサをビデオにより撮 影し，プリカーサが膨張する様子を観察した画像を示す。昇 温速度は $2 \mathrm{~K} / \mathrm{s}$ とし, 加熱時間は試料温度が $400^{\circ} \mathrm{C}$ に到達し た時点を基準 $(t=0 \mathrm{~s})$ としている。これらの写真から，プリ カーサの膨張量を定量的に評価するために（1）式で示した 相対投影面積を算出した。Fig. 4 に AZ91 合金プリカーサの 温度と相対投影面積の経時变化を示す。プリカーサ温度が， $420^{\circ} \mathrm{C}$ を過ぎた時点から徐々に膨張を開始し, $600^{\circ} \mathrm{C}$ 付近か
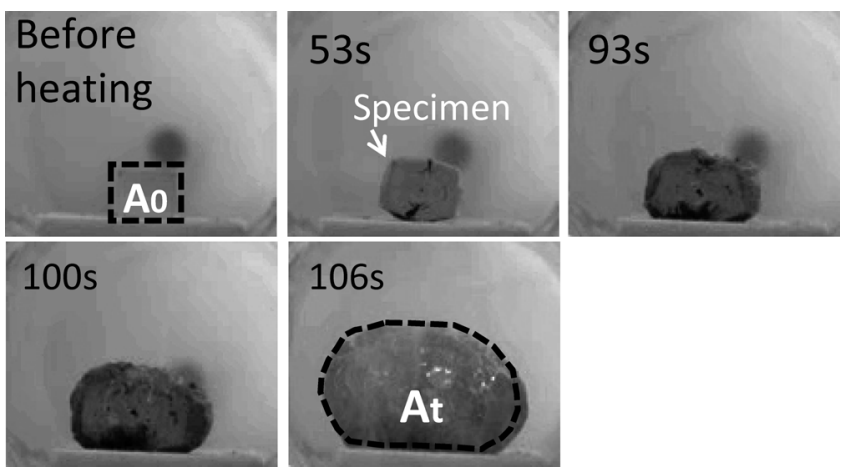

Fig. 3 Sequential photos of AZ91 magnesium precursor at various heating time $\left(A_{0}\right.$ : Projected area before heating, $A_{t}$ : Projected area during heating).

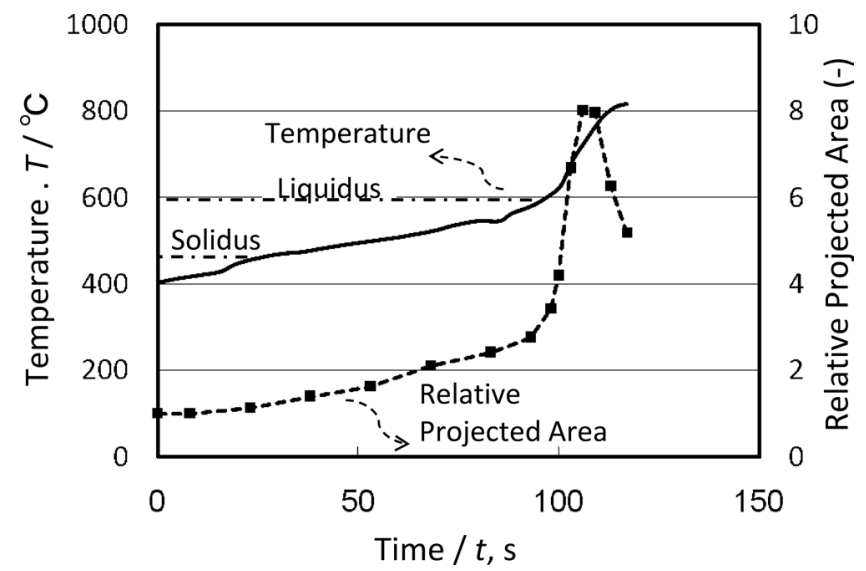

Fig. 4 Foaming behavior of AZ91 magnesium precursor as a function of heating time.

ら，急速に膨張速度が増加した。AZ91 合金の固相線および 液相線温度は，それぞれ $470^{\circ} \mathrm{C}$ おび $595^{\circ} \mathrm{C}$ とれている が ${ }^{14)}$, 実際の溶解開始温度は $420^{\circ} \mathrm{C}$ であることも知られてい る。また, $\mathrm{TiH}_{2}$ は, $390^{\circ} \mathrm{C}$ から分解を始め, $415 \sim 440^{\circ} \mathrm{C}$ で明 確な水素ガスの放出が見られるようになることが報告されて (る15) 17)。これらの事実から，本実験における発泡過程は， プリカーサ温度が $420^{\circ} \mathrm{C}$ 付近を超えた時点で, AZ91 合金の 溶解と $\mathrm{TiH}_{2}$ からのガス発生がほぼ同時に生じ, さらに液相 線温度を超えて液相の粘性が低下することにより, 急速に膨 張速度が上昇ということが理解できる。また，この条件では 最大相対投影面積が 8.0 程度となり，AZ91 合金プリカーサは 非常に発泡しやすい材料であることがわかった。しかしなが ら, 最大発泡状態を維持する時間は数秒程度と短く, 加熱を 継続することにより急速に収縮することも明白である。

\section{2 昇温速度の影響}

平均昇温速度を $1 \mathrm{~K} / \mathrm{s}, 2 \mathrm{~K} / \mathrm{s}, 3 \mathrm{~K} / \mathrm{s}$ としてプリカーサの加熱 を行い, 加熱時間と相対投影面積の関係を測定した結果を Fig. 5 に示す。平均昇温速度が増加するにつれて, 相対投影 面積が最大值に達するまでの時間が短くなり, 最大相対投影 面積の值は大きくなった。次に, 投影面積が最大となった時 点で He ガスによる強制冷却を行った試料の断面写真を Fig. 6 に示す。平均昇温速度が $3 \mathrm{~K} / \mathrm{s}$ のとき, 径の小さい気孔の 割合が最む多かった。次に, 気孔率, 断面あたりの気孔数, 気孔径をアルキメデス法, 画像解析により算出した。それら の結果を, Fig. 7 に示す。平均昇温速度が増加するにつれて, 


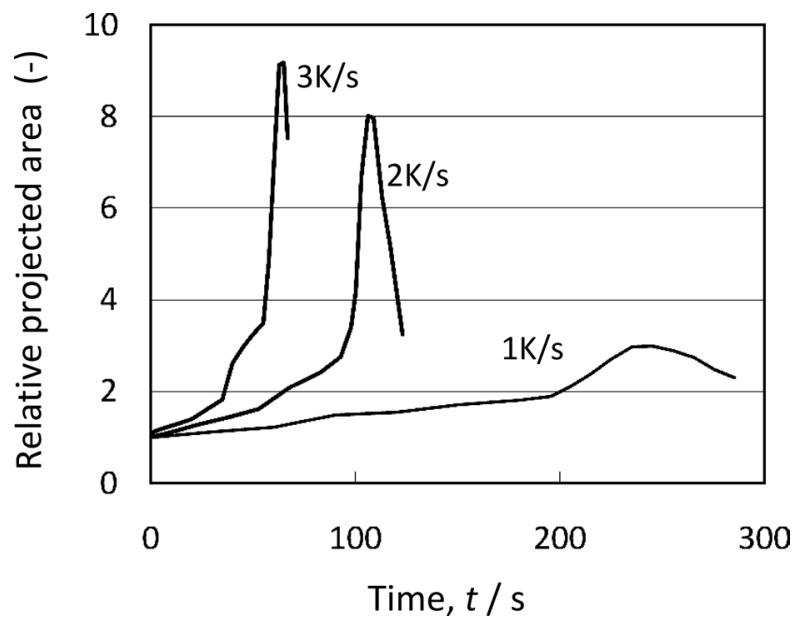

Fig. 5 Effect of heating rate on foaming behavior of AZ91 magnesium precursor.

Heating rate
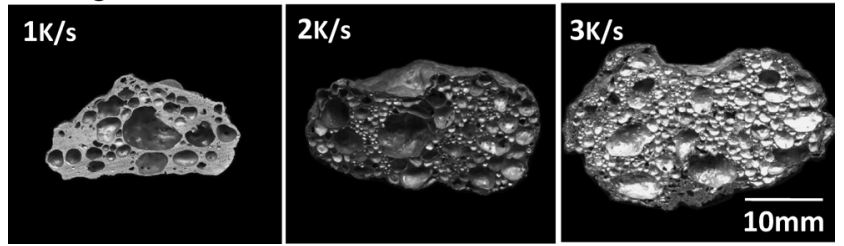

Fig. 6 Cross sections of porous AZ91 magnesium fabricated at various heating rate.
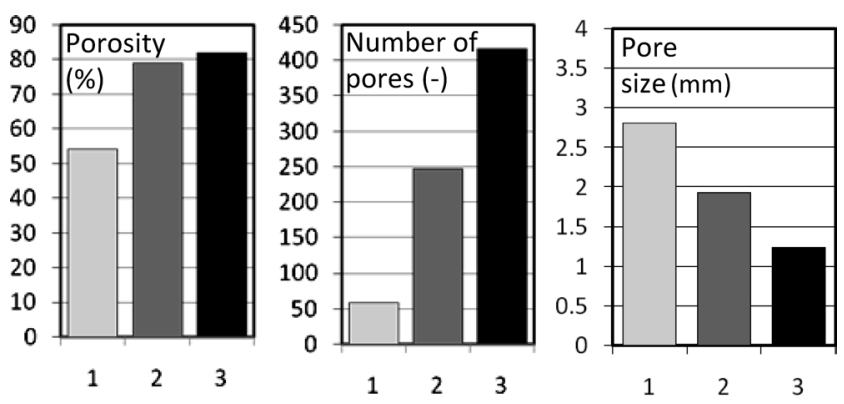

Heating rate, $\dot{T} / \mathrm{K} / \mathrm{s}$

Fig. 7 Porosity, number of pores and pore size of porous AZ91magnesium fabricated by various heating rate.

気孔率抒よび気孔数が増加し, 気孔サイズは減少しているこ とが定量的に示された。この理由として, 昇温速度により, 試料作製に要する時間が異なることが挙げられる。液相を利 用したポーラス金属製造時に気泡を包む液膜中を液相が重力

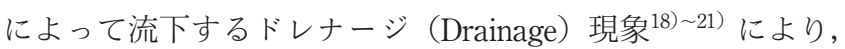
液膜が薄くなり，気孔が破壊にいたることが知られている。 本実験で, 液相が出現する固相線温度から最大発泡に達する までに要する時間を測定した結果, 平均昇温速度 $1 \mathrm{~K} / \mathrm{s}, 2 \mathrm{~K} / \mathrm{s}$, $3 \mathrm{~K} / \mathrm{s}$ の場合について，それぞれ $125 \mathrm{~s}, 67 \mathrm{~s}, 35 \mathrm{~s}$ であった。す なわち, 昇温速度を速くすることにより, 液相が生成してか ら冷却されるまでの時間が短縮されることで, ドレナージ現 象, および, 気孔の合体が抑制され, 細か、気孔が数多く分 散したものと考えられる。

\section{3 加熱温度の影響}

平均昇温速度 $3 \mathrm{~K} / \mathrm{s}$ で加熱を行い, 試料温度が $540^{\circ} \mathrm{C}$ から
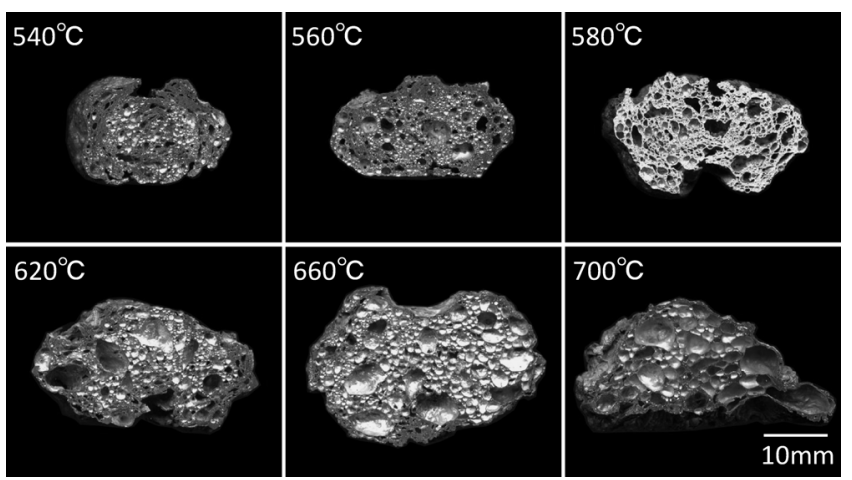

Fig. 8 Cross sections of porous AZ91 magnesium fabricated at various temperatures (heating rate: $3 \mathrm{~K} / \mathrm{s}$, He gas cooling).

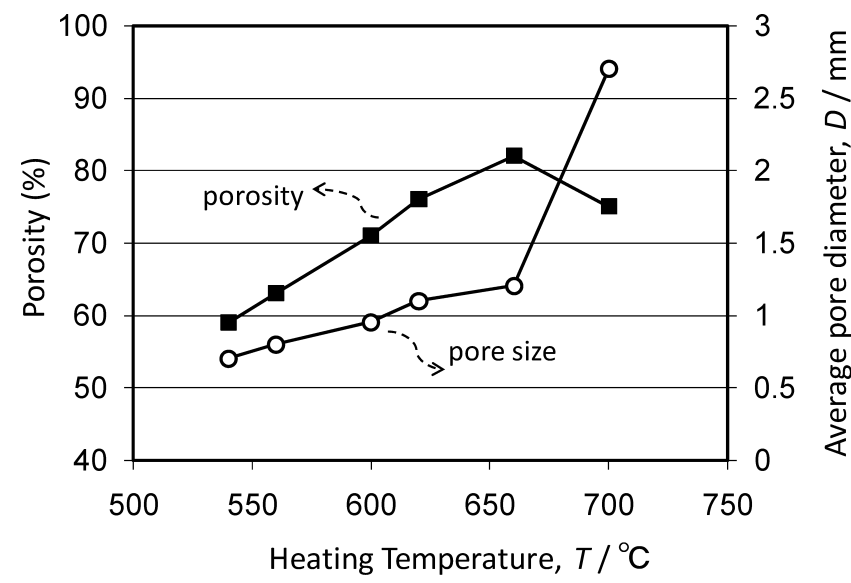

Fig. 9 Porosity and pore size of porous AZ91 magnesium fabricated at various temperatures (heating rate: $3 \mathrm{~K} / \mathrm{s}, \mathrm{He}$ gas cooling).

$700^{\circ} \mathrm{C}$ の所定温度に到達した時点で, He ガス吹付けによる強 制冷却を行った試料の断面写真を Fig. 8 に示す。また，加熱 温度と気孔率および気孔径（平均相当円直径）の関係を Fig. 9 に示す。加熱温度が $660^{\circ} \mathrm{C}$ までは温度の上昇とともに気孔 率が増加し, $660^{\circ} \mathrm{C}$ で最大気孔率 $82 \%$ を示した後, 加熱温度 $700^{\circ} \mathrm{C}$ では気孔率 $75 \%$ と減少した。また気孔径は $540^{\circ} \mathrm{C}$ から $700^{\circ} \mathrm{C}$ まで温度の上昇とともに増加し続け, 特に最大発泡の $660^{\circ} \mathrm{C}$ から $700^{\circ} \mathrm{C}$ の間で大きく増加した。最大発泡を超えた $700^{\circ} \mathrm{C}$ まで昇温すると, 気孔同士の合体が顕著になり, 粗大 な気孔の数が増加したと考えられる。

\section{4 冷却速度の影響}

平均昇温速度を $3 \mathrm{~K} / \mathrm{s}$ として, $540^{\circ} \mathrm{C}$ から $660^{\circ} \mathrm{C}$ の各温度ま でプリカーサを加熱した後に, 炉内自然冷却により試料を作 製した。Fig. 10 に $660^{\circ} \mathrm{C}$ で炉内自然冷却を行った試料之, He ガス強制冷却を行った試料の温度履歴を示す。 He ガス強 制冷却により $660^{\circ} \mathrm{C}$ から液相線温度である $595^{\circ} \mathrm{C}$ までは, $2 \mathrm{~s}$ ほどで到達するのに対して, 自然冷却では, $11 \mathrm{~s}$ を要した。 $540 \sim 660^{\circ} \mathrm{C}$ の各温度で加熱を停止し, 自然冷却した試料の断 面写真を Fig. 11 に示す。He ガス強制冷却を行った試料 （Fig. 8）とは異なり, 加熱温度が $660^{\circ} \mathrm{C}$ の試料では, 気孔が 重力方向に潰れてしまっている。次に, 自然冷却抢よび He ガス強制冷却を行った試料の加熱温度と気孔率の関係を Fig. 
12 に示す。気孔率は加熱温度が液相線温度以下である $540^{\circ} \mathrm{C}$ から $580^{\circ} \mathrm{C}$ までは，自然冷却試料と $\mathrm{He}$ ガス強制冷却試料の 間の差は比較的小さかった。しかし，加熱温度が液相線温度 以上である $620^{\circ} \mathrm{C}, 660^{\circ} \mathrm{C}$ と高くなるにつれて, He ガス強制冷 却では気孔率が大きくなった。一方で, 自然冷却では気孔率 が増加せず， $660^{\circ} \mathrm{C}$ まで加熱した試料では，気孔率 $37 \%$ と大 きく減少した。自然冷却では試料の凝固が始まる前に溶融マ

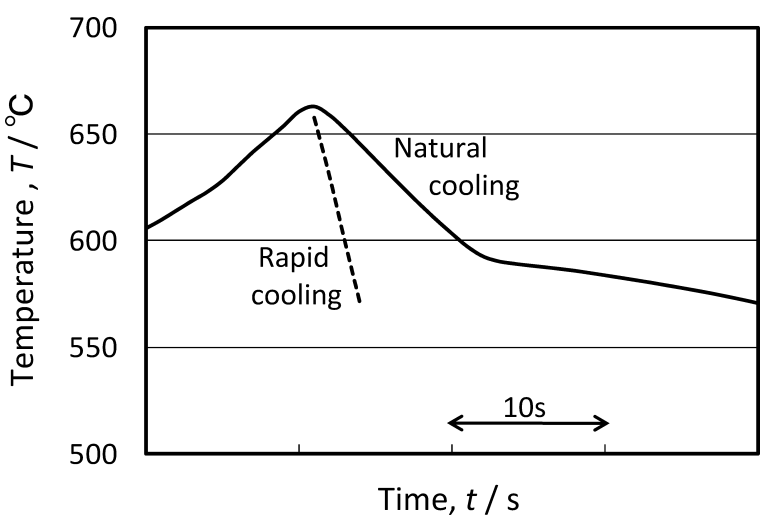

Fig. 10 Temperature profile of rapidly and naturally cooled specimens.
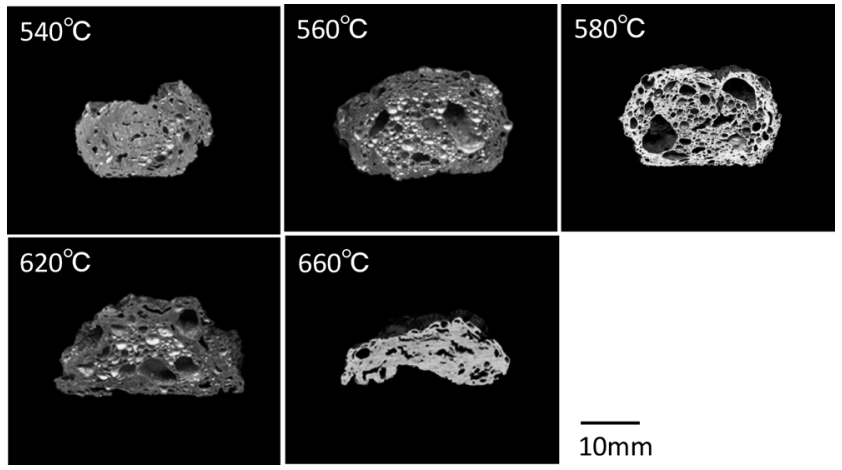

Fig. 11 Cross sections of porous AZ91 magnesium fabricated at various temperatures (heating rate: $3 \mathrm{~K} / \mathrm{s}$, natural cooling).

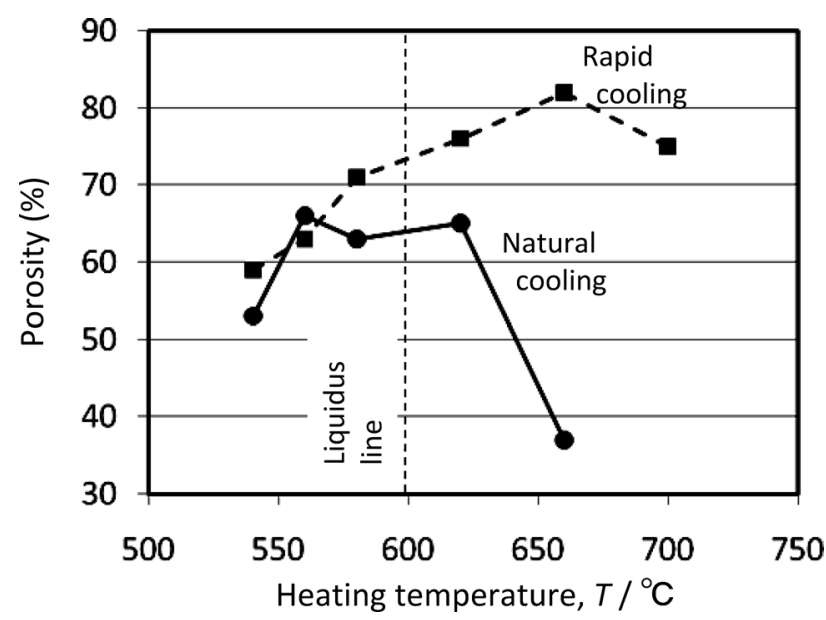

Fig. 12 Porosity of porous AZ91 magnesium fabricated at various temperatures by rapid and natural cooling processes.
グネシウムのドレナージによって液膜が薄くなり, 気孔が潰 れてしまったのに対し, He ガス強制冷却では, 気孔が潰れる 前に凝固を開始させることができるため, 高気孔率を維持し た状態の試料を作製可能であった。本実験の結果より, 液相 線温度を超えてポーラスマグネシウムを作製する際には, 加 熱発泡後に急速に冷却することが必要不可欠であることがわ かった。

\section{4. 結言}

圧縮ね じり加工により $\mathrm{AZ} 91$ 合金チップ, $\mathrm{TiH}_{2}$ 粉末から成 形したプリカーサの加熱および冷却条件が発泡特性, 気孔性 状に及ぼす影響を検討し，以下の結果を得た。

（1）プリカーサは AZ91 合金の固相線温度付近から膨張を 開始し, 液相線温度を超えると, 膨張の速度が著しく上昇し た。最大発泡を維持するのは, 数秒程度の極めて短時間であ り，その後，急速に収縮した。

（2）平均昇温速度が $1 \sim 3 \mathrm{~K} / \mathrm{s}$ の範囲では, 昇温速度が増加 するにつれて, 相対投影面積の最大值は増加し, 最大に達す るまでの時間が短くなった。また, 最大発泡時に He ガス冷 却した試料の気孔率, 気孔数は昇温速度の増加とともに増加 し，気孔サイズは減少した。

（3）加熱温度が AZ91 合金の液相線温度以上の場合, 粗大 な気孔がみられ，気孔サイズのばらつきが大きくなった。

（4）最大加熱温度が液相線温度以下の場合, 気孔率は冷却 速度の影響を受けなかったのに対し, 最大加熱温度が液相線 温度以上である場合, 冷却速度が遅いと気孔率は大きく減少 した。

\section{参 考 文 献}

1) J. Banhart: Adv. Eng. Mater., 8 (2006), 781-794.

2) J. Baumeister, J. Banhart and M. Weber: Mater. \& Design, 18 (1997), 217-220.

3) H. N. G. Wadley: Adv. Eng. Mater., 4 (2002), 726-733.

4) S. Ramachandra, P. S. Kumar and U. Ramamurty: Scr. Mater., 49 (2003), 741-745.

5) J. Banhart: Progress in Mater. Sci., 46 (2001), 559-632.

6) F. Baumgartner, I. Duarte and J. Banhart: Adv. Eng. Mater., 4 (2002), 168-174.

7）小橋 眞，金武直幸：まてりあ， 47 (2008), 178-181.

8) S. Tsuda, M. Kobashi and N. Kanetake: Mater. Trans., 47 (2006), 2125-2130.

9) N. Kanetake, M. Kobashi and S. Tsuda: Adv. Eng. Mater., 10 (2008), 840-844.

10) K. Maehara, M. Kobashi and N. Kanetake: Adv. Mater. Res., 26-28 (2007), 905-908.

11) C. C. Yang and H. Nakae: J. of Mat. Proc. Tech., 141 (2003), 202-206.

12) I. Duarte and J. Banhart: Acta Mater., 48 (2000), 2349-2362.

13）小橋 眞, 棚橋伸也, 金武直幸: 軽金属, 53 (2003), 427-432.

14）日本マグネシウム協会編：マグネシウム技術便覧，（2000），58.

15） B. Matijasevic-Lux, J. Banhart, S. Fiechter, O. Gorke and N. Wanderka: Acta Mater., 54 (2006), 1887-1900.

16) A. R. Kennedy, V. H. Lopez: Mater. Sci. Eng., A357 (2003), 258-263.

17) A. R. Kennedy: Scr. Mater., 47 (2002), 763-767.

18） JIS H7009 ポーラス金属用語（編集 島 弘志），日本規格協会， (2008), 6.

19) V. Gergely and T. W. Clyne: Acta Mater., 52 (2004), 3047-3058.

20) J. Banhart and H. Stanzick: App. Phys. Let., 78 (2001), 1152-1154.

21) S. Asavavisithchai and A. R. Kennedy: Scr. Mater., 54 (2006), 13311334. 